\title{
Water Saving Strategy in Rice by Alternate Wetting and Drying Technology
}

\author{
Prakshipta Boruah* A. Sarma and K.N. Das \\ Department of Agronomy, Assam Agricultural University, Jorhat-785013, Assam, India \\ *Corresponding author
}

\begin{tabular}{l} 
Ke y w o r d s \\
Water saving \\
strategy, Rice, \\
Drying technology \\
\hline Article Info \\
\hline $\begin{array}{l}\text { Accepted: } \\
\text { 12 February } 2018 \\
\text { Available Online: } \\
\text { 10 March } 2018\end{array}$ \\
\hline
\end{tabular}

A B S T R A C T

A field experiment was conducted during 2016 and 2017 at Instructionalcum-Research (ICR) Farm of Assam Agricultural University, Jorhat to work out the optimum irrigation scheduling on the transplanted autumn rice with alternate wetting and drying technology. In both the years, irrigation at $15 \mathrm{~cm}$ depletion of water from soil surface gave the highest grain yield and straw yield. The growth characteristics in terms of plant height, number of tillers per hill, CGR and RGR and yield attributing characteristics like number of effective tillers per hill, length of panicle, number of grains per panicle recorded the highest values under irrigation at $15 \mathrm{~cm}$ depletion of soil surface. The treatment also recorded the highest Crop Water Use Efficiency during both the years. The benefit: cost ratio was also found to be highest under this treatment.

\section{Introduction}

In Assam, rice occupies about 2.54 million hectares i.e., two-third of the gross cropped area of 4.16 million hectares (Anonymous, 2016) It contributes 96 per cent to the total food grain production of the state. The agroclimatic variation of the state is mainly responsible for the classification of rice growing seasons- sali (winter rice), boro (summer rice) and $a h u$ (autumn rice), which is based on the time of harvest. Among these, ahu rice is photoperiod insensitive, early maturing and grown as direct seeded crop as rainfed or transplanted crop with irrigation.
Irrigation strongly influences the rice yield. With current practices, the rice crop consumes large quantity of irrigation water, ranging between 1500 and $3000 \mathrm{~mm}$ (Sharma et al., 2002; Singh et al., 2002). Rice is considered as one of the most important factor for fall in water table in central Punjab of India (Singh, 2006). Recent water shortages in reservoirs causes problems as insufficient water and fallow rice fields; therefore, comparing irrigation water requirements and crop production of paddy fields using a technique that differs from the conventional flood irrigation method is important (Kuo, 2014). Therefore, it is felt that there is a need to save 
water in rice cultivation, which led to development of alternative methods of cultivation i.e., alternate wetting and drying (AWD), Alternate wetting and drying is such a water saving technology in rice production that can reduce the number of irrigations as compared to farmers' conventional practice, thereby lowering irrigation water consumption by $23 \%$ (Bouman and Tuong, 2001) to $38 \%$ (Lampayan et al., 2015).

\section{Materials and Methods}

A field experiment was conducted for two years (2016 and 2017) at Instructional-CumResearch (ICR) Farm of Assam Agricultural University, Jorhat, India during the $a h u$ season in transplanted autumn rice based on the alternate wetting and drying technology of IRRI to work out the irrigation scheduling in the crop and to find out its growth, development and yield of the crop under this irrigation technology. The climatic condition of Jorhat is sub-tropical humid with hot summer and cold winter. Normally, monsoon starts from the month of June and continues up to the month of September with the occurrence of low pre-monsoon showers from mid March. During 2016 and 2017, the total amount of rainfall received was $1106.10 \mathrm{~mm}$ and $698 \mathrm{~mm}$ with a maximum average weekly rainfall of $258.6 \mathrm{~mm}$ and $115.9 \mathrm{~mm}$, respectively. The weekly mean maximum temperature ranged from 17.7 to $27.8{ }^{\circ} \mathrm{C}$ during 2016 and 14.9 to $26.6{ }^{\circ} \mathrm{C}$ during 2017 . Weekly mean minimum temperature ranged from 16.9 to $26.7{ }^{\circ} \mathrm{C}$ and 14.4 to $26.2{ }^{\circ} \mathrm{C}$ during 2016 and 2017, respectively. The weekly average relative humidity ranged from 88.1 to $97.0 \%$ during the morning hours and 55.8 to $90.7 \%$ in the evening hours during 2016. During 2017, morning and evening relative humidity ranged from 90.4 to $96.7 \%$ and 60 to $82.1 \%$, respectively. The experiment was laid out in randomized block design (RBD) and replicated thrice. The treatments consisted of eight irrigation regimes viz., irrigation at $5 \mathrm{~cm}$ depletion of water from soil surface $\left(\mathrm{T}_{1}\right)$, irrigation at $10 \mathrm{~cm}$ depletion of water from soil surface $\left(\mathrm{T}_{2}\right)$, irrigation at 15 $\mathrm{cm}$ depletion of water from soil surface $\left(\mathrm{T}_{3}\right)$, irrigation at $20 \mathrm{~cm}$ depletion of water from soil surface $\left(\mathrm{T}_{4}\right)$, irrigation at $25 \mathrm{~cm}$ depletion of water from soil surface $\left(\mathrm{T}_{5}\right)$, irrigation at 30 $\mathrm{cm}$ depletion of water from soil surface $\left(\mathrm{T}_{6}\right)$, irrigation at 3 days after disappearance of ponded water $\left(\mathrm{T}_{7}\right)$ and continuous flooding $\left(\mathrm{T}_{8}\right)$. All plots received $\mathrm{N}-\mathrm{P}_{2} \mathrm{O}_{5}-\mathrm{K}_{2} \mathrm{O}$ at recommended dose of $40-20-20 \mathrm{~kg} / \mathrm{ha}$ in the form of Urea, Single Super Phosphate (SSP) and Muriate of Potash (MOP), respectively, where $\mathrm{N}$ was applied in 2 split doses. Half $\mathrm{N}$ and full $\mathrm{P}_{2} \mathrm{O}_{5}$ and $\mathrm{K}_{2} \mathrm{O}$ were applied at final puddling. Remaining half $\mathrm{N}$ was applied at panicle initiation stage. The rice variety "Dishang" was sown on $23^{\text {rd }}$ February, transplanted on $15^{\text {th }}$ March and harvested on $18^{\text {th }}$ June during 2016 whereas during 2017, it was sown on $24^{\text {th }}$ February, transplanted on $22^{\text {nd }}$ March and harvested on $19^{\text {th }}$ June. The soil of the experimental plots were silty loam in texture, acidic in reaction ( $\mathrm{pH} 5.5$ ), medium in organic carbon $(0.63 \%)$, low in low in alkaline $\mathrm{KMnO}_{4}$ extractable $\mathrm{N}(171.31 \mathrm{~kg} / \mathrm{ha})$, medium in Brays I P (10.1 kg/ha) and medium in $1 \mathrm{~N}$ ammonium acetate extractable $\mathrm{K}$ (212.1 $\mathrm{kg} / \mathrm{ha})$. The field capacity was found to be $27.45 \%$ while permanent wilting point was $7.70 \%$. For chemical analysis, plant samples were oven dried at $65^{\circ} \mathrm{C}$ to a constant weight and grounded to reduce the material to a fineness suitable size by using a mechanical grinder. Samples were digested in diacid mixture of $\mathrm{H}_{2} \mathrm{SO}_{4}$ and $\mathrm{HClO}_{4}$ in the ratio of 9: 1 for nutrient $\mathrm{N}$ estimation. $\mathrm{P}$ and $\mathrm{K}$ were estimated by Vanadomolybdate method and flame photometer method respectively. The nutrient uptake $(\mathrm{kg} / \mathrm{ha})$ by the crop was calculated by multiplying the grain yield per plot $(\mathrm{kg} / \mathrm{ha})$ with the nutrient content of the grain (\%). The data were analyzed statistically and the mean differences among the treatment 
means were evaluated by the least significance difference (LSD) at 5\% level of probability (Sarma, 2016). For economic analysis, all input costs including the cost for lease of land and interest on running capital were considered for computing the cost of production. Leaf Area Index (LAI), Leaf Area Duration (LAD), Crop Growth Rate (CGR) and Relative Growth Rate (RGR) were calculated as per standard formula.

\section{Results and Discussion}

\section{Effect of irrigation scheduling on growth parameters}

The study revealed that the morphological characteristics of the plant including plant height, LAI, LAD, CGR, RGR showed significant differences among the treatments (Table 1, Figs. 1 and 2). The highest plant height was recorded by $15 \mathrm{~cm}$ depletion of water from soil surface $\left(\mathrm{T}_{3}\right)$ which was at par with depletion of $5 \mathrm{~cm}\left(\mathrm{~T}_{1}\right)$ and $10 \mathrm{~cm}\left(\mathrm{~T}_{2}\right)$ irrigation water, irrigation at 3 DADPW $\left(\mathrm{T}_{7}\right)$ and continuous flooding $\left(\mathrm{T}_{8}\right)$. Similarly, $15 \mathrm{~cm}$ depletion of water from soil surface $\left(\mathrm{T}_{3}\right)$ being at par with depletion of $5 \mathrm{~cm}\left(\mathrm{~T}_{1}\right)$ and $10 \mathrm{~cm}$ $\left(\mathrm{T}_{2}\right)$ of irrigation water, irrigation at 3 DADPW $\left(\mathrm{T}_{7}\right)$ and continuous flooding $\left(\mathrm{T}_{8}\right)$ recorded the highest LAD. The lowest plant height and LAD were recorded by $5 \mathrm{~cm}$ irrigation at $30 \mathrm{~cm}$ depletion of water from soil surface $\left(\mathrm{T}_{6}\right)$.

CGR was found to increase statistically from 0-30 DAT to 30-60 DAT and then decreased at 60-90 DAT. However, RGR was highest at 0-30 DAT and gradually decreased at 30-60 DAT to 60-90 DAT. All the growth characteristics recorded the highest values under irrigation at $15 \mathrm{~cm}$ depletion of water from soil surface $\left(\mathrm{T}_{3}\right)$. Better growth parameters under these treatments could be due to improved root growth with alternate wetting and drying (AWD) enabling greater access to water and nutrients at depth in the soil profile which is in line with the earlier findings of Yang et al., (2009).

Effect of irrigation scheduling on yield attributing characters and yield

In both the years, yield attributing characters like effective tillers per hill, panicle length and number of grains per panicle were found to be highest under irrigation at $15 \mathrm{~cm}$ depletion of water from soil surface $\left(\mathrm{T}_{3}\right)$ (Table 2). However, depletion of $5 \mathrm{~cm}\left(\mathrm{~T}_{1}\right)$ and $10 \mathrm{~cm}$ $\left(\mathrm{T}_{2}\right)$ of irrigation water and irrigation at 3 DADPW $\left(\mathrm{T}_{7}\right)$ were at par with $\mathrm{T}_{3}$. However, 1000 seed weight and harvest index were found to be non-significant. AWD is beneficial in maintaining yield attributes and grain yield of rice were also reported by Bouman and Tuong (2001).

In both the years, the highest grain and straw yield was obtained from irrigation at $15 \mathrm{~cm}$ depletion of water from soil surface $\left(T_{3}\right)$ which was followed by irrigation at $10 \mathrm{~cm}$ deletion of water from soil surface $\left(\mathrm{T}_{2}\right)$ and irrigation at $5 \mathrm{~cm}$ depletion of water from soil surface $\left(\mathrm{T}_{1}\right)$ and irrigation at $3 \mathrm{DADPW}$, all being at par. Yang et al., (2017) reported that increases in grain yield under moderate AWD were due mainly to improved canopy structure and root growth, elevated hormonal levels, in particular increases in abscisic acid levels during soil drying and cytokinin levels during rewatering and enhanced carbon remobilization from vegetative tissues to grain.

\section{Effect of irrigation scheduling on water use and water use efficiency}

Lowest irrigation water was used in irrigation at $30 \mathrm{~cm}$ depletion of water from soil surface ( $\left.\mathrm{T}_{6}\right)$ followed by irrigation at $25 \mathrm{~cm}\left(\mathrm{~T}_{5}\right), 20$ $\mathrm{cm}\left(\mathrm{T}_{4}\right)$ and $15 \mathrm{~cm}\left(\mathrm{~T}_{3}\right)$ depletion of water from soil surface (Table 3 ). 
Table.1 Plant height, LAI and LAD as influenced by irrigation scheduling

\begin{tabular}{|c|c|c|c|c|c|c|c|c|}
\hline \multirow[t]{3}{*}{ Treatment } & \multicolumn{2}{|c|}{$\begin{array}{c}\text { Plant height at } \\
\text { harvest }(\mathbf{c m})\end{array}$} & \multicolumn{4}{|c|}{ LAI } & \multirow{2}{*}{\multicolumn{2}{|c|}{$\begin{array}{c}\text { LAD } \\
\text { (days) }\end{array}$}} \\
\hline & \multirow[t]{2}{*}{2016} & \multirow[t]{2}{*}{2017} & \multicolumn{2}{|c|}{$30 \mathrm{DAT}$} & \multicolumn{2}{|c|}{$60 \mathrm{DAT}$} & & \\
\hline & & & 2016 & 2017 & 2016 & 2017 & 2016 & 2017 \\
\hline$T_{1}$ & 90.3 & 91.1 & 1.60 & 1.71 & 4.32 & 4.61 & 213.0 & 225.0 \\
\hline $\mathbf{T}_{2}$ & 90.4 & 91.6 & 1.65 & 1.77 & 4.81 & 5.11 & 231.2 & 243.8 \\
\hline$T_{3}$ & 91.2 & 91.9 & 1.76 & 1.89 & 4.93 & 5.25 & 240.2 & 253.7 \\
\hline $\mathbf{T}_{4}$ & 81.2 & 87.3 & 1.45 & 1.52 & 4.11 & 4.29 & 202.8 & 210.3 \\
\hline$T_{5}$ & 81.1 & 82.0 & 1.31 & 1.39 & 3.85 & 4.01 & 186.3 & 193.5 \\
\hline$T_{6}$ & 79.8 & 80.1 & 1.25 & 1.35 & 3.61 & 3.89 & 171.3 & 182.7 \\
\hline $\mathbf{T}_{7}$ & 90.4 & 91.7 & 1.73 & 1.82 & 4.77 & 5.21 & 232.1 & 248.0 \\
\hline $\mathrm{T}_{8}$ & 89.8 & 90.1 & 1.37 & 1.47 & 4.14 & 4.42 & 199.4 & 210.8 \\
\hline $\mathrm{SEm} \pm$ & 2.8 & 2.7 & 0.08 & 0.10 & 0.23 & 0.27 & 10.8 & 11.9 \\
\hline $\mathrm{CD}(\mathrm{P}=0.05)$ & 8.5 & 8.1 & 0.25 & 0.31 & 0.70 & 0.85 & 32.8 & 36.1 \\
\hline
\end{tabular}

Table.2 Yield attributing characters of rice as influenced by irrigation scheduling

\begin{tabular}{|c|c|c|c|c|c|c|c|c|c|c|c|c|c|c|}
\hline \multirow[t]{2}{*}{ Treatment } & \multicolumn{2}{|c|}{$\begin{array}{c}\text { Effective } \\
\text { tillers/hill }\end{array}$} & \multicolumn{2}{|c|}{$\begin{array}{c}\text { Length of } \\
\text { panicle }(\mathrm{cm})\end{array}$} & \multicolumn{2}{|c|}{$\begin{array}{c}\text { Number of } \\
\text { grains/ panicle }\end{array}$} & \multicolumn{2}{|c|}{$\begin{array}{l}\text { Test weight } \\
\text { (g) }\end{array}$} & \multicolumn{2}{|c|}{$\begin{array}{l}\text { Grain yield } \\
\text { (t/ha) }\end{array}$} & \multicolumn{2}{|c|}{$\begin{array}{c}\text { Straw yield } \\
(\mathbf{t} / \mathbf{h a})\end{array}$} & \multicolumn{2}{|c|}{ Harvest Index } \\
\hline & 2016 & 2017 & 2016 & 2017 & 2016 & 2017 & 2016 & 2017 & 2016 & 2017 & 2016 & 2017 & 2016 & 2017 \\
\hline$T_{1}$ & 7.7 & 7.9 & 23.0 & 24.1 & 74.0 & 78.7 & 23.3 & 23.0 & 3.91 & 4.24 & 5.97 & 6.89 & 0.39 & 0.38 \\
\hline $\mathbf{T}_{2}$ & 7.9 & 8.1 & 23.7 & 24.3 & 75.2 & 79.4 & 23.0 & 23.0 & 4.19 & 4.42 & 6.21 & 6.97 & 0.40 & 0.39 \\
\hline $\mathbf{T}_{3}$ & 8.0 & 8.4 & 23.9 & 24.6 & 76.9 & 80.0 & 23.3 & 23.0 & 4.28 & 4.52 & 6.32 & 7.07 & 0.41 & 0.39 \\
\hline$T_{4}$ & 7.1 & 7.5 & 21.3 & 22.3 & 67.2 & 71.9 & 22.7 & 22.9 & 3.51 & 3.89 & 5.29 & 6.25 & 0.40 & 0.38 \\
\hline $\mathbf{T}_{5}$ & 7.1 & 7.3 & 21.0 & 22.0 & 66.3 & 71.6 & 23.0 & 22.9 & 3.38 & 3.85 & 5.22 & 6.20 & 0.40 & 0.38 \\
\hline $\mathrm{T}_{6}$ & 7.0 & 7.2 & 20.3 & 21.4 & 65.2 & 69.1 & 22.7 & 22.9 & 3.31 & 3.52 & 5.09 & 6.00 & 0.39 & 0.37 \\
\hline $\mathbf{T}_{7}$ & 7.7 & 8.1 & 23.3 & 24.2 & 75.0 & 75.7 & 22.7 & 22.9 & 4.02 & 4.26 & 6.11 & 6.75 & 0.40 & 0.39 \\
\hline $\mathrm{T}_{8}$ & 6.9 & 7.1 & 23.0 & 24.0 & 75.0 & 79.6 & 22.7 & 23.0 & 3.71 & 4.01 & 6.11 & 6.65 & 0.38 & 0.38 \\
\hline $\mathrm{SEm}+$ & 0.2 & 0.2 & 0.8 & 0.7 & 2.9 & 2.6 & 0.9 & 0.4 & 0.16 & 0.20 & 0.34 & 0.33 & 0.03 & 0.04 \\
\hline CD & 0.7 & 0.7 & 2.5 & 2.1 & 8.7 & 7.9 & NS & NS & 0.49 & 0.59 & 0.80 & 0.78 & NS & NS \\
\hline
\end{tabular}




\section{Int.J.Curr.Microbiol.App.Sci (2018) 7(3): 1333-1340}

Table.3 Yield of rice as influenced by irrigation scheduling

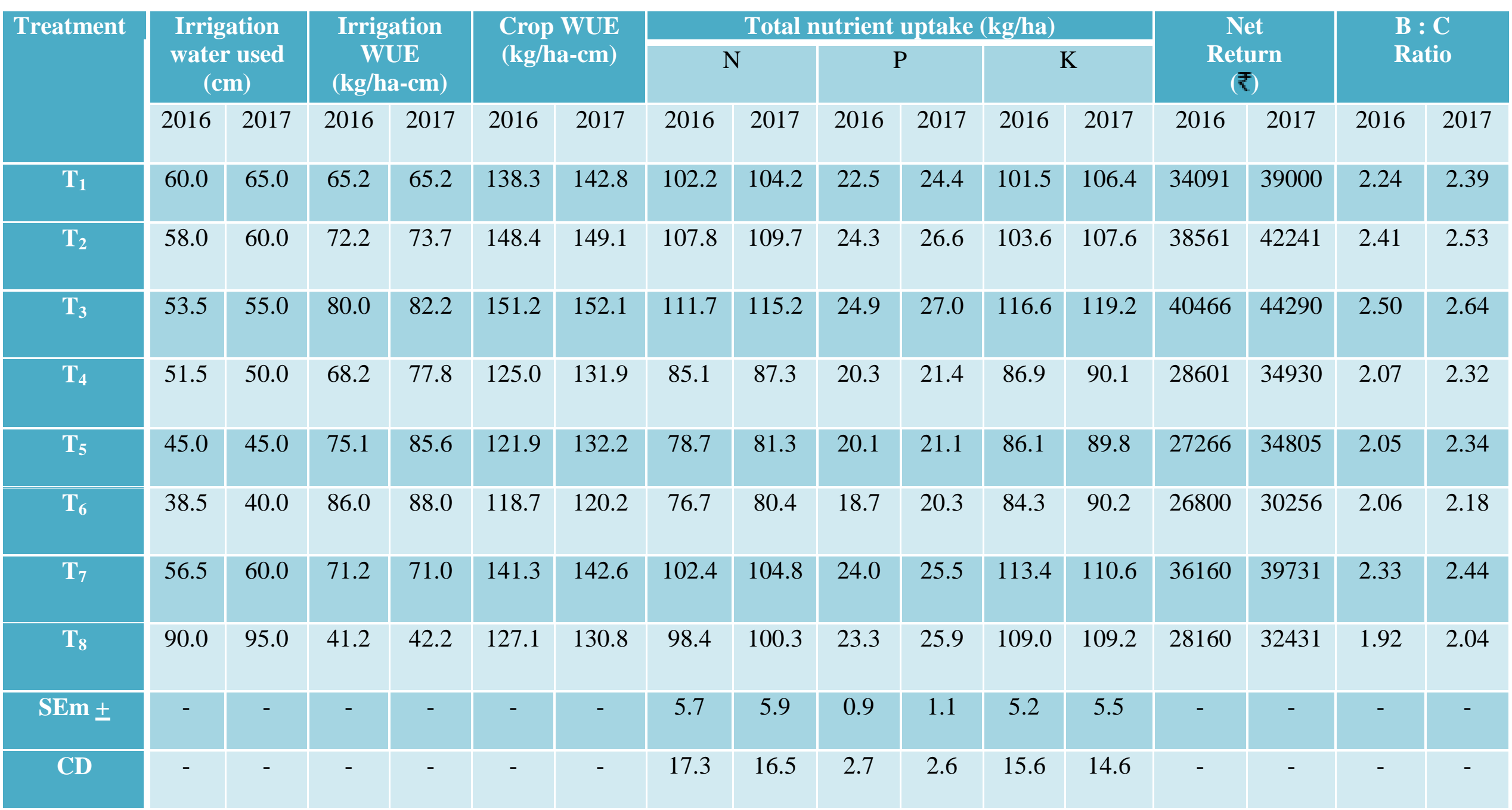


Fig.1 CGR at 30 days interval as influenced by irrigation scheduling
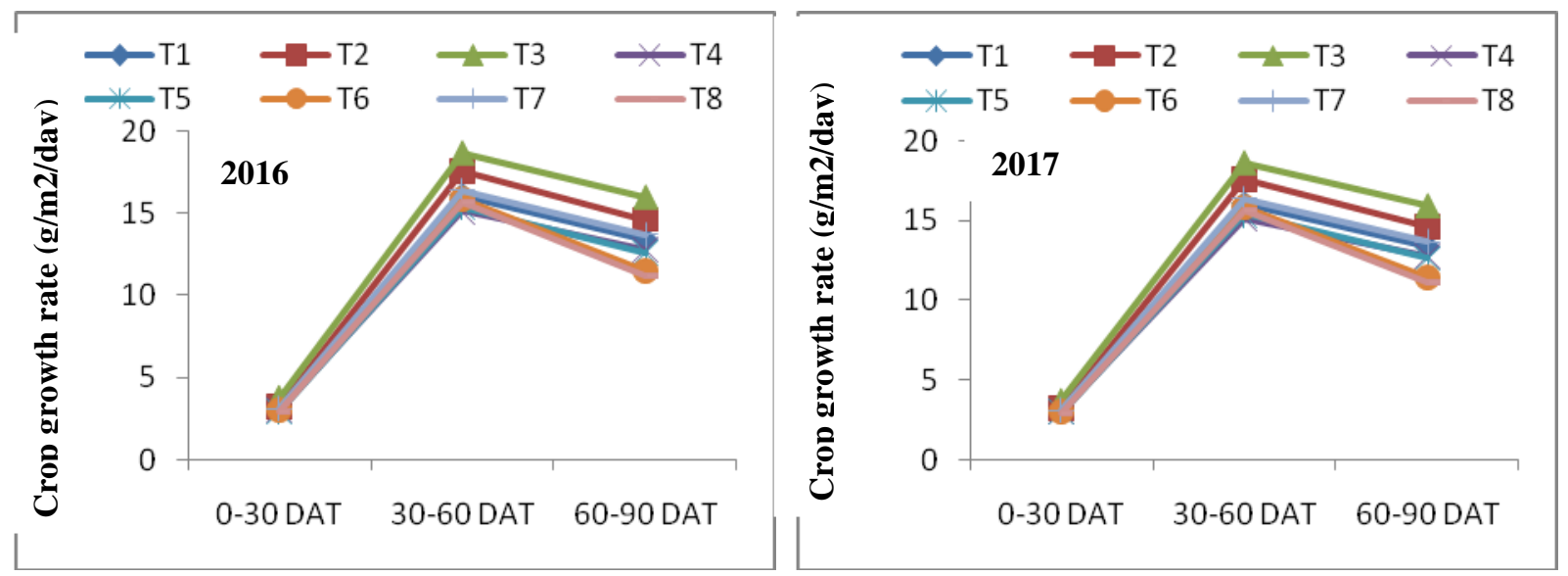

Fig.2 RGR at 30 days interval as influenced by irrigation scheduling

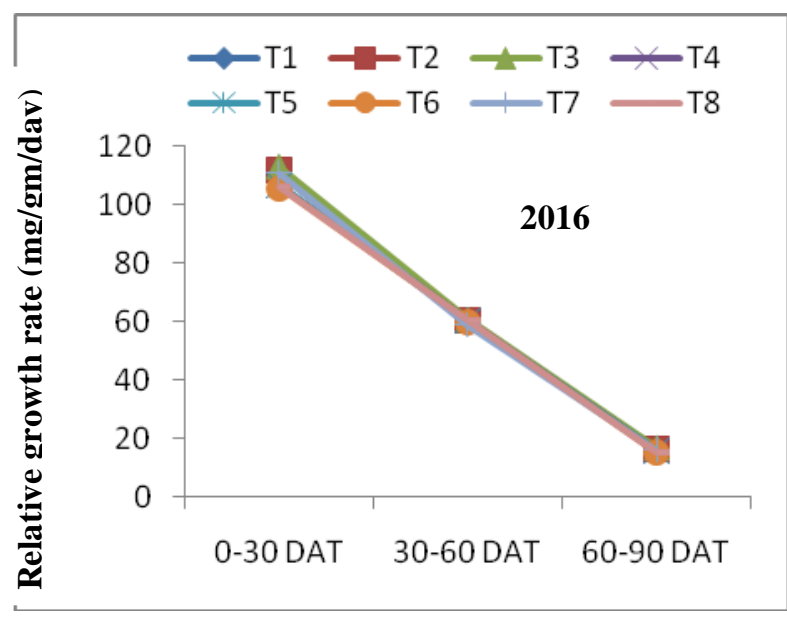

The highest water was used under continuous flooding $\left(\mathrm{T}_{8}\right)$. Irrigation at $30 \mathrm{~cm}$ depletion of water from soil surface $\left(\mathrm{T}_{6}\right)$ also recorded the highest irrigation water use efficiency and was closely followed by irrigation at $15 \mathrm{~cm}$ depletion of water from soil surface $\left(\mathrm{T}_{3}\right)$. However, irrigation at $15 \mathrm{~cm}$ depletion of water from soil surface $\left(\mathrm{T}_{3}\right)$ recorded the highest water use efficiency. The lowest irrigation water use efficiency and water use efficiency were recorded under continuous flooding. Higher consumptive use of water with continuous flooding might be due to the fact that under more frequent wetting cycle, evaporation was higher due to the availability of more water as compared to the crop

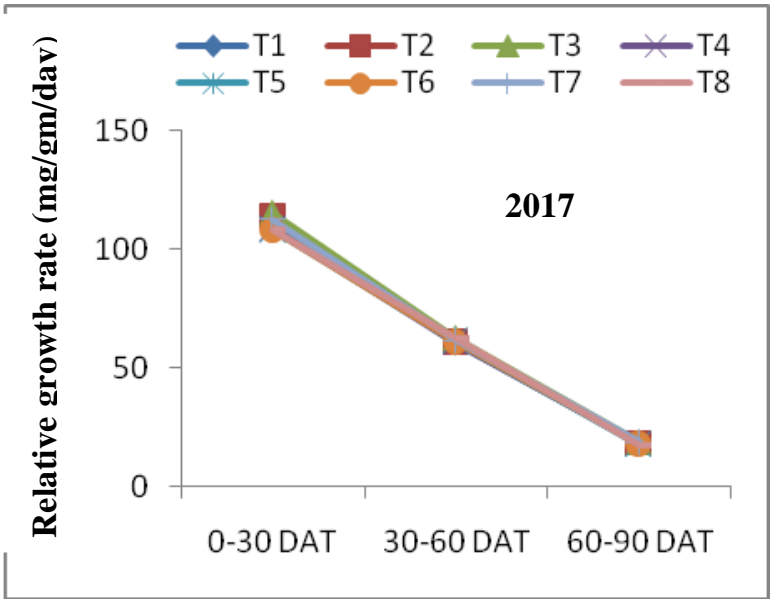

irrigated at wider interval. These findings are in general agreement with those of Singh et al., (2001); Yadav et al., (2011) and Sarma and Das (2013). Thus, there was an increase in yield with water saving of $16.92 \%$ in 2016 and $21.85 \%$ in 2017 over continuous flooding.

\section{Effect of irrigation scheduling on nutrient uptake}

The effect of different irrigation treatments on nitrogen, phosphorus and potassium uptake by grain and straw was found to be significant (Table 3). Irrigation at $15 \mathrm{~cm}$ depletion of water from soil surface $\left(T_{3}\right)$ being at par with 
depletion of $5 \mathrm{~cm}\left(\mathrm{~T}_{1}\right)$ and $10 \mathrm{~cm}\left(\mathrm{~T}_{2}\right)$ water from soil surface, irrigation at $3 \mathrm{DADPW}\left(\mathrm{T}_{7}\right)$ and continuous flooding $\left(\mathrm{T}_{8}\right)$ recorded the highest $\mathrm{N}, \mathrm{P}$ and $\mathrm{K}$ uptake. The increase in nutrient uptake could be attributed to welldeveloped root system under alternate wetting and drying and availability of soil held nutrients to the rice plant resulting in better absorption of water and nutrients that increased the dry matter as well as higher $\mathrm{N}$, $\mathrm{P}$ and $\mathrm{K}$ concentration in plants. These findings are in general agreement with those of Tuong and Bouman (2002), Shimono and Bunce (2009) and Somaweera et al., (2016).

\section{Effect of irrigation scheduling on economics of rice}

Irrigation at $15 \mathrm{~cm}$ depletion of water from soil surface $\left(T_{3}\right)$ recorded the highest net return ( $₹ 40,466$ and $₹ 44,290$ ) and BenefitCost ratio (2.50 and 2.64) during both the years (Table 3). It was closely followed by irrigation at $10 \mathrm{~cm}$ depletion of water from soil surface (₹ 38,562; ₹ 42,241 and 2.41; 2.53 ) and 3 DADPW (₹36,160; ₹ 39,731 and $2.33 ; 2.44)$. The lowest net return was recorded under irrigation at $30 \mathrm{~cm}$ depletion of water from soil surface (₹ 26,800; ₹ 30,256) while the lowest Benefit-Cost ratio was observed under continuous flooding (1.92; 2.04). Nalley et al., (2015) also investigated the economic viability of different AWD treatments and found the lowest profit in the treatment with highest water productivity.

Thus, it could be concluded that in early $a h u$ rice, crop should be irrigated at $15 \mathrm{~cm}$ depletion of water from the soil surface.

\section{References}

Anonymous (2016). Statistical Hand Book, Assam. Directorate of Economics and
Statistics, Government of Assam, Guwahati-28.

Bouman, B.A.M. and Tuong, T.P. (2001). Field water management to save water and increase its productivity in irrigated lowland rice.Agric Water Mngt. 49:11-30.

Kuo, S. F. (2014). Evaluation of irrigation water requirements and crop yields with different irrigation schedules for paddy fields in ChiaNan irrigated area, Taiwan. Paddy Water Environment. 12: 71-78.

Lampayan, R. M., Rejesus, R. M., Singleton, G. R. and Bouman, B. A. M. (2015). Adoption and economics of alternate wetting and drying water management for irrigated lowland rice. Field Crops Research. 170: 95-108.

Nalley, L.L., Linquist, B., Kovacs, K.F. and Anders, M.M. (2015). The economic viability of alternate wettimg and drying irrigation in Arkansas rice production. Agron. J. 107:579-587.

Sarma, A. (2016). Agricultural statistics for field and laboratory experimentation. Kalyani Publishers, New Delhi.

Sarma, A. and Das, J.C. (2013). Effect of irrigation and fertilizer on growth, yield, nutrient uptake and water use by coriander (Coriandrum Sativum L.). Adv. in Pl Sci. 26(2): 485-488.

Sharma, P. K., Bhushan, L., Ladha, J. K., Naresh, R. K., Gupta, R. K., Balasubramanian, B. V. and Bouman, B. A. M. (2002). Crop-water relations in rice-wheat cropping under different tillage systems and water management practices in a marginally sodic, medium textured soil. In: Bouman, B.A.M., Hengsdijk, H., Hardy, B., Bindraban, P.S., Tuong, T.P. and Ladha, J.K. (Eds.), Water-Wise Rice Production. I.R.R.I., Los Banos, Philippines. pp. 223-235. 
Shimono, H. and Bunce, J.A. (2009) Acclimation of nitrogen uptake capacity of rice to elevated atmospheric $\mathrm{CO}_{2}$ concentration. Ann Bot. 103: 87-94.

Singh, A. K., Choudhury, B. U. and Bouman, B. A. M. (2002). Effects of rice establishment methods on crop performance, water use and mineral nitrogen. In: Bouman, B.A.M., Hengsdijk, H., Hardy, B., Bindraban, P.S., Tuong and T.P., Ladha, J.K. (Eds.), Water-Wise Rice Production. I.R.R.I., Los Banos, Philippines. pp. 237-246.

Singh, K. (2006). Fall in Water Table in Central Punjab How Serious? Tech. Bull. The Punjab State Farmers Commission. Government of Punjab, Mohali, Punjab, India. p 10.

Singh, K.B., Gajri, P.R. and Arora, V.K. (2001). Modelling the effects of soil and water management practices on the water balance and performance of rice. Agric. Water Mngt. 49: 77-95.

Somaweera, K.A.T.N., Suriyagoda, L.D.B., Sirisena, D.N. and De Costa, W.A.J.M. (2016). Accumulation and partitioning of biomass, nitrogen, phosphorus and potassium among different tissues during the life cycle of rice grown under different water management regimes. Plant and Soil. 401: 169-183.

Tuong, T.P. and Bouman, B.A.M. (2002) Rice production in water-scarce environments. Proceedings of the water productivity workshop, 12-14 November 2001. International Water Management Institute (IWMI), Sri Lanka.

Yadav, S., Humphreys, E., Kukal, S.S., Gill, G. and Rangarajan, R. (2011). Effect of water management on dry seeded and puddled transplanted rice Part 2: Water balance and water productivity. Field Crops Res. 120: 123-132.

Yang, J., Huang, D., Duan, H., Tan, G. and Zhang, J. (2009). Alternate wetting and moderate soil drying increases grain yield and reduces cadmium accumulation in rice grains. J. Sci. Food Agric.,. 89: 1728-1736.

Yang, J., Zhou, Q. and Zhang, J. (2017). Moderate wetting and drying increases rice yield and reduces water use, grain arsenic level, and methane emission. The Crop J. 5(2):151-158.

\section{How to cite this article:}

Prakshipta Boruah, A. Sarma and Das, K.N. 2018. Water Saving Strategy in Rice by Alternate Wetting and Drying Technology. Int.J.Curr.Microbiol.App.Sci. 7(03): 1333-1340. doi: https://doi.org/10.20546/ijcmas.2018.703.159 